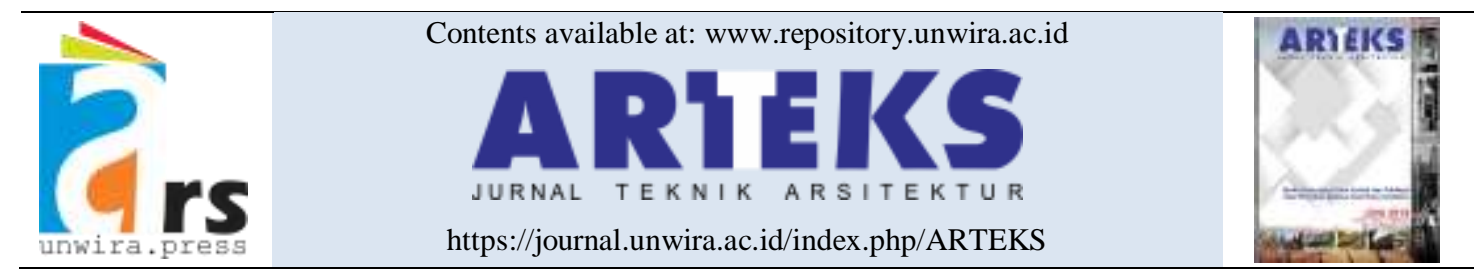

Conceptual paper

doi: http://doi.org/10.30822/arteks.v3i2.65

\title{
Human, nature, and architecture
}

\section{Johannes Widodo}

Department of Architecture, School of Design and Environment, National University of Singapore 4 Architecture Drive, Singapore 117566, Republic of Singapore

\begin{tabular}{|c|c|}
\hline ARTICLE INFO & ABSTRACT \\
\hline $\begin{array}{l}\text { Article history: } \\
\text { Received October } 01,2018 \\
\text { Received in revised form Nov. } 02,2018 \\
\text { Accepted November } 20,2018 \\
\text { Available online June } 01,2019\end{array}$ & $\begin{array}{l}\text { To understand: Human is the centre of natural exploitation and built } \\
\text { environment, a belief that has been existed since the beginning of } \\
\text { civilization when human started to adapt into the natural } \\
\text { environment and to articulate nature into built-environment. } \\
\text { Human as creator and innovator of the built environment put himself } \\
\text { at the centre of the universe: geographically is at the middle ground }\end{array}$ \\
\hline $\begin{array}{l}\text { Corresponding author: Johannes Widodo } \\
\text { Departemen of Architecture, School of } \\
\text { Design and Environment, National } \\
\text { University of Singapore } \\
\text { Email: jwidodo@ nus.edu.sg } \\
\text { ORCID: https://orcid.org/0000-0003-2522- } \\
7351\end{array}$ & $\begin{array}{l}\text { in between the mountain and the waterfront, chronologically is in } \\
\text { between the sunrise and the sunset, and ideologically is in between } \\
\text { heaven above and underworld beneath the earth. He stands at the } \\
\text { middle of circles that define inside and outside and denote sacred } \\
\text { and profane. } \\
\text { Water is the essence of life. Therefore, the forested hills and } \\
\text { mountains that provide steady supply of fresh water are preserved } \\
\text { and well protected, spiritually and physically. To ensure the } \\
\text { continuous flow of the lifeline, the forests are protected against } \\
\text { violations and destructions, through rituals and social rules. The } \\
\text { choice of location for the built-up area of the settlement is carefully } \\
\text { considered against natural and supra-natural factors, in order to } \\
\text { ensure the harmonious relationships between human, nature, and } \\
\text { the spirits. In rational sense, it is to ensure the survivability of the } \\
\text { community's existence and its livelihood. }\end{array}$ \\
\hline
\end{tabular}

\section{To adapt}

The vernacular building typology is the result of adaptation to local climate, innovation in building materials and techniques, and creative integration of belief, function, and form. Pitch roof, wide eaves, raised floor, breathing roof, and porous walls are the responses against the equatorial tropical warm-humid climate, affected by monsoon with plenty of rain, and to ensure comfort for people who lives within it. The timber construction system using flexible joints are reactions against earthquakes, especially in the Indonesian archipelago, which are continuously rocked by active volcanoes and the movement of continental plates.

On the land-based farming settlement in the warm-humid tropical region of Southeast Asia, the vernacular stilt-house typology was developed out of the rice growing culture, originated from granary architectural typology, which was then further developed into dwelling (Waterson 2009).

From the earliest vernacular traditions of Southeast Asia, we learned that local architecture and native urbanism can offer the best and integrated solution towards human needs in the relation with nature, human, and spiritual environments through symbolism. It is the vehicle for human survival in both physical and spiritual worlds, a reconciliation of the power of nature and the desires of human being (Janowski and Waterson 1996), (Waterson 1990).

Adaptation is the simplest way of creating space and shelter that does not harm the nature, energy efficient, and therefore offering the most sustainable solution to human needs. Trees can 
provide shadows, flow of fresh air, cooler temperature, and oxygen supply. Umbrella, sun shading, and veranda can be effective devices to increase bodily comfort and additional protection against rain and wind. Sustainability and liveability can be achieved naturally and effortlessly, and therefore affordably.

\section{To make}

Architecture is a process of creating space or making place for human physical, social, cultural, economic, and spiritual needs. Mangunwijaya called it "architecturing", as well as the Indian call the art of architecturing as "vastu-shastra". Human is always put at the middle of the Architect's creation.

An amphitheatre at the courtyard of the Faculty of Engineering building of UNTAG Semarang was built from scratch by the Architecture students from all batches, including their alumni and other volunteers, supervised by some staffs, in just 3 weeks in September 2018. The planning, design, building, and finishing process have managed to bring peoples together in collaborative manner, generating sense of belonging and strong comradery. The open-air theatre under the shadow of the trees and the building's air well has become a cosy gathering and hanging out place; and provides additional space for teaching and public talks.

Another example is the main building of Widya Mandala University in Surabaya, designed by architect Rusli in 1996. Brickworks of East Javanese Hindu temples, and the roof of Puh Sarang Catholic church designed by Ir Henri Maclaine Pont in 1930s, in an attempt to contextualize the architecture into local architectural culture and religion, inspire the overall building style (Rigg 1996). The main structures are exposed steel, with the implementation of direct electrical current technology, adopted from shipbuilding industry one of the main industries in Surabaya - to prevent rusting process. Both structural system and the direct current technology were implemented to save cost (speed of construction, lightweight structure, no cost for painting and maintenance). Another important feature is the walls, made by high quality hollow-bricks, put together to create openings for ventilation and natural lighting. The furniture was made using recycled woods and leftover materials from the construction site. The specially and cleverly designed staff 's table with transparent glass tabletop is a symbolical gesture of - nothing hidden under the tablell (transparence, honesty, no-corruption), organized in very efficient but yet comfortable open-plan office layout.

\section{To nature}

Both examples above demonstrate that consider human, nature, and architecture as one holistic entity. These are the breeding grounds for responsible and capable individuals who will become agent for change in making the world a better place for living, a more sustainable place to raise the future generations, and a liveable home for everyone (Widodo 2004).

Function refers to usage or services that man gets, and capacity that increases human capability. Form refers to image, meaningful reflection for human who lives in it. Form is related to level of culture, while Function is related to level of civilization. Every material has its own language, and we have to be sensitive to the message it conveys and to its characteristics. Design process is problem solving that moves from inside to outside. Therefore, it is fundamental to gain understanding about the fundamental problems and potentials from the inside, before we can generate the resolutions through Architecture (Widodo 2012).

Human, fauna, flora and the environment are one entity like a human body with its limbs. Everything is interrelated and interconnected. Planet Earth is one ecosystem, a sum of unified and interconnected organic and integrated life. Our building has to bear common responsibility to manage and to preserve our environment (Widodo 2016).

The traditional practices, knowledge, and knowhow, which have been tested and implemented for generations for its efficiency, effectiveness, and sustainability, should be pushed forward into wider public debates, academic discourses, and political processes on sustainability and climate change. Possible sociopolitical-cultural barriers which prevent the integration of cultural heritage paradigms into the current urban planning and development discourses should be understood and properly responded, so local wisdoms can be effectively 
repositioned in the current architectural design and urban planning praxis.

\section{References}

Janowski, Monica, and Roxana Waterson. 1996. "The Living House: An Anthropology of Architecture in South-East Asia." The Journal of the Royal Anthropological Institute. https://doi.org/10.2307/3034107.

Rigg, Jonathan. 1996. INDONESIAN HERITAGE SERIES - THE INDONESIAN HERITAGE SERIES: THE HUMAN ENVIRONMENT. 2nd ed. Singapore: Grolier International Inc.

Waterson, Roxana. 1990. "Houses and the Built Environment in Island South-East Asia: Tracing Some Shared Themes in the Uses of Space." The Living House: An Anthropology of Architecture in South-East Asia.

2009. Paths and Rivers; Sa'dan Toraja Society in Transformation. Paths and Rivers; Sa'dan Toraja Society in Transformation. https://doi.org/10.26530/oapen_377535.

Widodo, Johannes. 2004. The Boat And The City: Chinese Diaspora And The Morphology Of Southeast Asian Coastal Cities (Architecture of Southeast Asian Coastal Cities). Singapore: Marshall Cavendish Academic.

- 2012. "Urban Environment and Human Behaviour: Learning from History and Local Wisdom." Procedia - Social and Behavioral Sciences. https://doi.org/10.1016/j.sbspro.2012.04.16 1.

- 2016. "Sustainability Lesson from Southeast Asia: Singapore Experience." International Journal on Livable Space. https://doi.org/10.25105/livas.v1i1.1627. 
ARTEKS : Jurnal Teknik Arsitektur, Volume. 3, Nomor 2, Juni 2019 eISSN 2541-1217; pSSN 2541-0598 